\title{
Environmental Change and Livelihood Activities in Hadejia-Nguru Wetlands of Yobe State, North East Nigeria
}

\author{
Yagana Bukar ${ }^{1}$, Abubakar K. Monguno ${ }^{1}$ \& Abubakar T. AbdulRahman ${ }^{1}$ \\ ${ }^{1}$ Department of Geography, University of Maiduguri, Nigeria \\ Correspondence: Yagana Bukar, Department of Geography, University of Maiduguri, Nigeria. E-mail: \\ bukar.yagana@yahoo.com
}

Received: November 11, 2020

Accepted: February 22021

Online Published: August 31, 2021

doi:10.5539/jgg.v13n1p1

URL: http://dx.doi.org/10.5539/jgg.v13n1p1

\begin{abstract}
The Hadejia-Nguru wetlands is an extensive area of flood plains located in the Sudano-Sahelian zone of north east Nigeria. The population rely heavily on natural resources for their livelihoods. In recent years, climatic vagaries, increasing populations and unregulated livelihood activities have significantly affected water and other resources availability and communities are faced with constant struggle of survival under a declining resource base. This study assessed the adverse effects of environmental change on resource users and how this influences their livelihood options. Understanding the perceptions, knowledge and practices of local resource users and what shapes their livelihood options is an area of critical importance that is currently under-researched in the area. This paper argues that to effectively influence policy and practice that support sustainable use of natural resources, it is important to not only understand resource user's knowledge and choices about their changing environment but how they utilize this knowledge in their actions and the overall impact on the environment. Mixed methods consisting of semi-structured questionnaire and Focus Group Discussions (FGD) based on two Participatory Rural Appraisal (PRA) tools (Village Timeline and Contextual Change) were utilized to solicit primary data. Environmental change in the area is accelerated by human activities and people have developed several local mechanisms of adapting to change. These adaptive measures could further be explored for developing policies and programs aimed at tackling the challenges of environmental change and resource decline.
\end{abstract}

Keywords: Hadejia-Nguru Wetlands, Environmental Change, Resource Decline, Livelihoods, Adaptation

\section{Background}

The Hadejia-Nguru wetlands is a RAMSAR (Note 1) recognized site of extensive flood plains found in the Sudano-Sahelian zone of Yobe State in Northeast Nigeria. The wetlands like other similar areas is faced with environmental changes that are observed to progress faster than in other ecosystems (Millennium Ecosystem Assessment, 2005; Blench 2013 BirdLife International, 2015). The area is currently undergoing rapid environmental deterioration largely as a result of climate change, fast-growing water demand, unregulated dam projects and other predatory economic activities (Blench 2013; Olalekan, 2014). The major threats facing the wetlands include population pressure, invasive typha grass, overgrazing, overfishing and shrinking of the floodplains because of diversion from dams, irrigation developments and drought (Idris 2008; 2013; Mohammed 2014; Olalekan 2014; Abubakar, 2016). Upstream developments have affected incoming water either through dams which alter the timing and size of flood flows or through diversion of surface or groundwater for irrigation activities. The main cause of unexpected reduction in extent of the flooded area is also linked to reoccurring drought which is a persistent, stochastic environmental problem facing most arid and semi-arid environments (UNEP, 2011).

Against this backdrop, the study examined the effect of environmental change on the people's livelihood options as well as coping and adaptation strategies to variability and change. Specifically, the study examined the effects of climatic variations and unregulated human activities on livelihood systems and as well as people's perceptions and responses to environmental change and degradation.

\section{Conceptual Framework}

All types of environments generally undergo change over time including increasing temperatures, changing 
precipitation patterns, more frequent and extreme weather events and other climatic vagaries. Environmental change often reduces the predictability of seasonal weather patterns, increase the frequency and intensity of severe weather events such as floods, cyclones, hurricanes and droughts. The process of change is accelerated through human activities that negatively impact the environment and significantly increase the production risks of local resource users namely farmers, livestock pastoralist, fishers and other natural resources-dependent populations.

One of the most rapidly changing and endangered ecosystems are wetlands, (including freshwater rivers, lakes, paddies, marshes and peatlands) which are disappearing faster than other ecosystems. Indeed, wetlands are particularly dynamic ecosystems shaped or destroyed by extreme natural events such as floods, storms or drought. More than $25 \%$ of wetland's plants and animals which comprise up to $40 \%$ of all the world's species are at risk of extinction and the stocks of remaining species are declining rapidly (Ecosystem Assessment,2005; IUCN, 2019). This trend has broad ramifications since wetlands are highly valuable and fragile ecosystems and their survival and maintenance is contingent on their human systems (Mortimore et al., 2009). This also underscores the need to understand local adaptation measures and practices which can then be incorporated within broader development policies, projects and programs (Lemos et al., 2007).

Environmental vulnerability resulting from change and variability can be adequately countered by building on local and customary adaptive practices that directly confront change and variability in the environment. Within this framework, the analysis transcends the coordinates of vulnerability to change by exploring the diverse portfolio of local adaptive practices that not only enhance livelihoods but also contribute to environmental sustainability. The analysis explores the capacity of wetlands ecosystem to maintain functionality while adjusting to variable changes. As Mortimore et al., (2009) observes, the persistence of Sahelien livelihoods through decades of declining rainfall and increasing temperatures provide support for this approach justifiably demonstrates describing the system as ecological terms as "unstable" but "resilient".

Adaptation in such environments therefore is mainly about tackling the effects of declining resource base and environmental degradation through building resilience and the capacity to cope with its physical and human impacts. The adaptation process is largely autonomous and private where individuals and households initiate and implement strategies in response to their changing environments. It is a continuous stream of activities, actions, and attitudes that inform decisions about all aspects of livelihoods that reflect existing socio-economic norms and processes.

Resilience on the other hand reflects the amount of change the system can undergo and still retain the same control on function and structure while maintaining options to develop (Carpenter et al., 2001). The type and magnitude of change to the system is not always predictable, but change will occur and systems are managed for flexibility rather than for maintaining stability. It argues the preposition that in spite of constraints, risks and difficulties, opportunities which are worth exploring still exist based on the resources and capabilities of the people and on inward investment (Mortimore et al., 2009). The resilience framework stresses the importance of the capability of the individual and the system to respond to and adapt to stress. It explores not only the threats associated with change but also the resilience or responsiveness in exploiting opportunities and resisting and recovering from the negative effects of a changing environment. A framework of the people's adaptive capacity supported by sound policy and research offer pathways to sustainability and development. It is an integrative approach which can help confront issues such as degradation, biodiversity loss and resource decline with renewed optimism by exploring local environmental knowledge and practices. In the same vein, it underscores the importance of incorporating local adaptation measures within broader development policies, projects and programs (Lemos et al., 2007) that aim to address environmental degradation in general.

\section{The Study Area}

The Hadejia-Nguru wetlands is an of extensive flood plains found in the Sudano-Sahelian zone of Yobe State in Northeast Nigeria. It is located on Latitude $10^{\circ} 22^{\prime} \mathrm{N}$ and Longitude $12^{\circ} 46^{\prime} \mathrm{E}$ with a catchment area of about area of about $3,500 \mathrm{~km}^{2}$. The wetland is formed by the convergence of two large rivers (Katagum-Jama'are \& the Hadejia River) which flow into an area of ancient sand dune, then split to form a complex system of swamps, marshes, lakes and ponds before forming as the river Yobe and drain in to Lake Chad (Thompson \& Polet, 2000).

The climate of the area is semi-arid influenced by the strong convection rain of the Inter-Tropical Convergence Zone (ITCZ). The connection between the southerly moist and the northerly dry tropical maritime air volume converge at the basin from the southwestern location around the month of April and May and reache the northern side in August creating seasonal precipitation with an average of 500mm (Thompson \& Polet 2000; Nguru Metrological Station, 2019). Data obtained from the Nguru Metrological Station (2019) indicate that annual 
rainfall of the area varies from $200 \mathrm{~mm}$ to $600 \mathrm{~mm}$. The rainfall is characterized by two distinct seasons; wet season (May- September) and dry season (October to April). There is mean minimum temperature of $12^{\circ} \mathrm{C}$ during the month of December to January, to a maximum of $45^{\circ} \mathrm{C}$ during the month of April ((Nguru Metrological Station, 2019)).

The wetland ecosystem comprises permanent lakes and seasonally flooded pools connected by a network of channels (Abubakar et al., 2016). It is an ecologically and economically rich habitat for biodiversity of various fauna and flora and a major tourism location for Palaearctic and Afrotropical migrant water birds (Eaton \& Sarch, 1997). The value of the wetlands resides in the ecosystem services it provides which are particularly precious in the Sudano-sahelian environment characterized by erratic water availability and resource scarcity. The area is additionally a unique migratory habitat for wildfowl and wader species from Palearctic regions and contain a number of forest reserves (Thompson \& Poulet, 2000. Figure 1 shows the map of the study area.

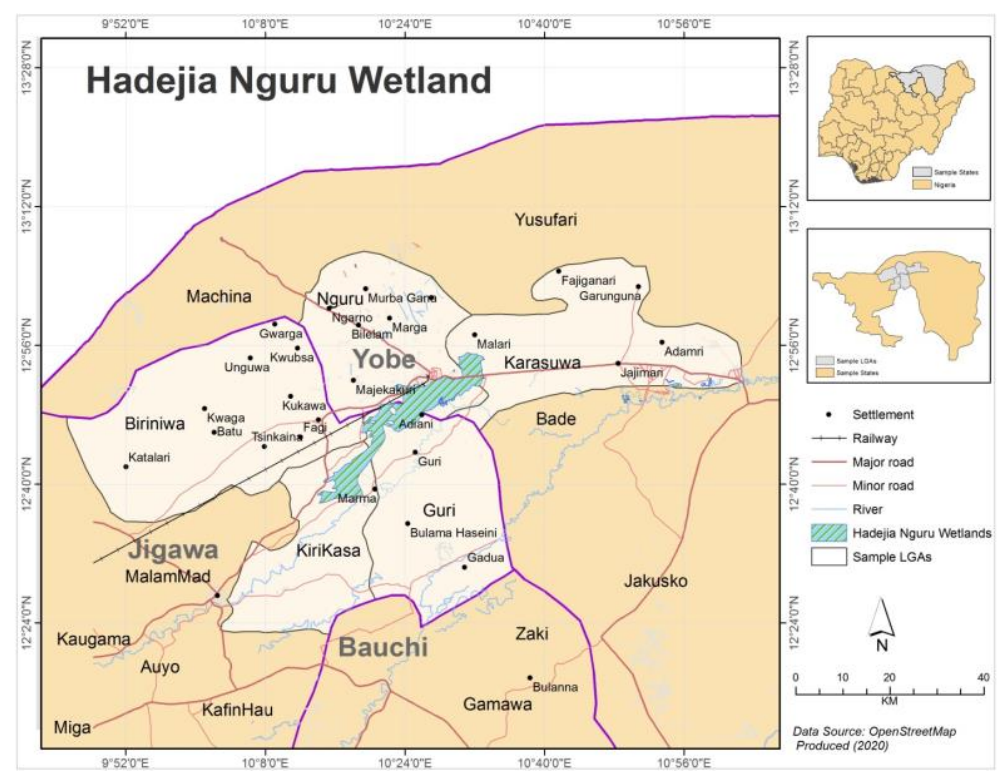

Figure 1. Map of Hadejia Nguru Wetland

People and Population: The population of the area is about 205,296 (Primary Health Care, Nguru, 2019). The area is pluralistic in ethnic composition with $60 \%$ Hausa-Fulani, $30 \%$ Kanuri and $10 \%$ other ethnic groups such as Yoruba, Igbo and Bade. The Fulani are mostly semi-settled herders but many also practice some arable farming and are more clearly separated from the other groups both by their culture and livelihood systems. Nguru has been one of Nigeria's major collecting points for gum Arabic, peanuts (groundnut), cotton, meat, hides, and skins to Lagos as a result of the railways, constructed during the colonial era.

Livelihood activities: Communities in the wetlands engage in a range natural resource based activities such as agriculture, fishing, livestock grazing and fuelwood extraction. The rich biodiversity of the area has enabled riparian communities to develop productive activities based on fishing, agriculture and livestock farming based on a complex system adapted to the variability of the environment and a mechanism for protection against droughts.

Agriculture in the area is traditionally rain-fed in the upland floodless areas which cover approximately half the wetlands surface area. A significant proportion of the population is engaged rainfed (tudu) farming and in dry season (fadama) farming. The principal crops grown include rice, maize, sesame, sorghum, wheat, millet, and some vegetables such as tomato, pepper, onions, and carrots. The permanent water bodies allow irrigation farming in areas liable to flooding, utilizing residual moistures left behind in the soil by inundation which relies on groundwater recharge of the Chad Formation aquifer and serves as "insurance" in times of drought (Thompson \& Hollis 1992).

The wetlands also serve wider regional economic purposes providing dry-season grazing for nomadic pastoralists. Indeed, the extensive grazing lands of the Hadejia-Nguru wetlands are highly attractive to pastoralists and it accommodates about 300,000,350,000 and 370,000 of cattle, goats and sheep respectively 
(Idris, 2008). In the dry season nomadic pastoralists migrate in to the area for grazing while the farmers also keep a few livestock. Fishing is a year-round activity which peaks during the seasons of up-coming and receding floods. Fisheries, although technically a wild resource, constitute a category of their own. Access rights in fisheries are strongly related to the nature of water flow. The most significant aspect of this is the ponds that form every dry season in certain zones. When the flood falls, large ponds, often rich in fish occur in roughly the same place every year. Several communities therefore fish throughout the year and rely mainly on fishing activities for their livelihoods.

The wetland was once rich in floral biodiversity and supported a large and diverse tree population. Nigeria's urban and rural population depends largely on fuel wood for cooking and the quest to supply this market has resulted in a highly efficient extraction, involving fuel wood gathering in both Protected Areas and outside and sale to entrepreneurs with trucks coming from Kano and other urban center (Idris, 2008).

\section{Methodology}

The study used a mixed methods design involving structured questionnaire and Focus Group Discussions (FGDs) to collect information from resource users namely farmers, pastoralists, fishermen and women from four selected communities located within the wetlands (Bambori, Dumsai, Kakori and Nguru town). A total of 302 respondents were interviewed with a set of questionnaire using accidental sampling. The sample size was considered sufficient to reach some level of generalization and to provide sufficient level for statistical analysis. settlements were selected in order to represent relatively 'large' and 'small' settlements. The open ended questions focused centrally on environmental problems and resource scarcity and how it has affected their livelihood outcomes.

FGDS and KIIs were conducted in selected communities with respondents including older people (men and women who have stayed for more than twenty-five years), local leaders, government officials and other stakeholders. The FGDs with about ten to twelve persons were conducted using Participatory Rural Appraisal (PRA) tools namely Contextual change and Village timelines. To capture respondent's experiences, the tools were used to explore the relationships between resource decline and livelihoods options in the area. Contextual change explored the changes that have occurred in the community over the years, the major factors behind such changes and how they have affected livelihoods choices. An illustration of village timelines provided a historical picture of all significant events that respondents could recall such as major climatic events, impacts on their livelihoods and adaptation to changes from their environment. Each of the interviews lasted about one hour. The interviews took place in their homes, farms, fishing and grazing settlements. Descriptive statistics was used in analyzing the data and salient issues were presented using tables, charts and cross tabulations. Qualitative analysis was used to analyzed the FGDs and the KIIs by discerning the key themes of the discussions. Publications, journals and other relevant were utilized to compliment the primary data. Two research assistants who understand the local language and culture were employed to assist in facilitating the interviews.

\section{Limitations and Relevance of the Study}

The research does not seek to assess the validity of the knowledge and perceptions currently held by communities regarding environmental change and its impact on livelihood activities or indeed local adaptation strategies, much of which are highly valid. Rather it identifies the importance of local knowledge in shaping practices and how this is often rooted in long term interaction with their environments, cultural norms and mediated by personal experiences. In such circumstances, understanding how local resource users frame their knowledge, what is important to them and what shapes their resilience and decisions become substantial and perhaps inform policy and programming for sustainable environmental management.

\section{Results and Discussion}

This section summarizes the main findings of this paper. It first describes the major environmental change and resource decline in the area and how it affect people's livelihoods. It later illustrates people's responses and adaptation strategies against these changes, specifically their involvement in alternative livelihood activities.

Environmental change in the area Different types of environmental change were reported to be occurring ascribed not only to the occurrence of physical hazards such as floods or droughts, but also to scarcity of water, pasture and other productive resources, as well as degradation of land. Accordingly, respondents reported that major changes include inadequate and fluctuating rainfall resulting in the overall reduction in water availability and recurrent droughts, Typha grass invasion, population pressure and unregulated human activities. FGD respondents perceive that today's climate is different from the past noting that the seasonal cycle and rainfall pattern have changed and the average temperature has increased during the dry season. Furthermore, droughts 
have become more frequent, soil productivity has declined, incidences of pest and diseases have increased. Overall, the views reflect a collective perspective that environmental change has negatively contributed to decline in environmental quality and resource availability as shown on Figure 2. The results further illustrate a high level of awareness and sensitivity to environmental changes among respondents. In tracing the timeline of major climatic events, most of the respondents noted that they began observing such changes 15-20 years ago (Figure 3).

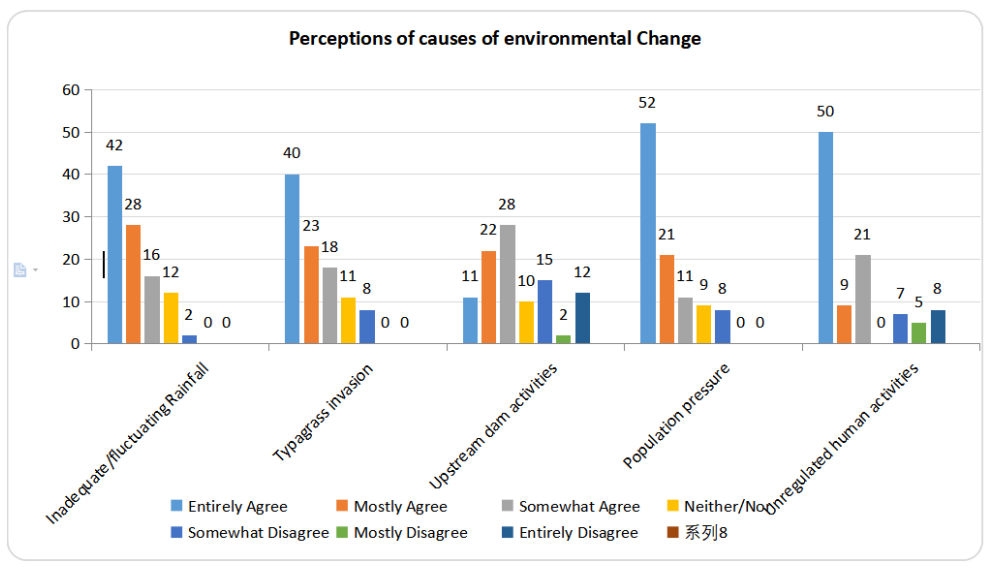

Figure 2. Cause of Environmental Change

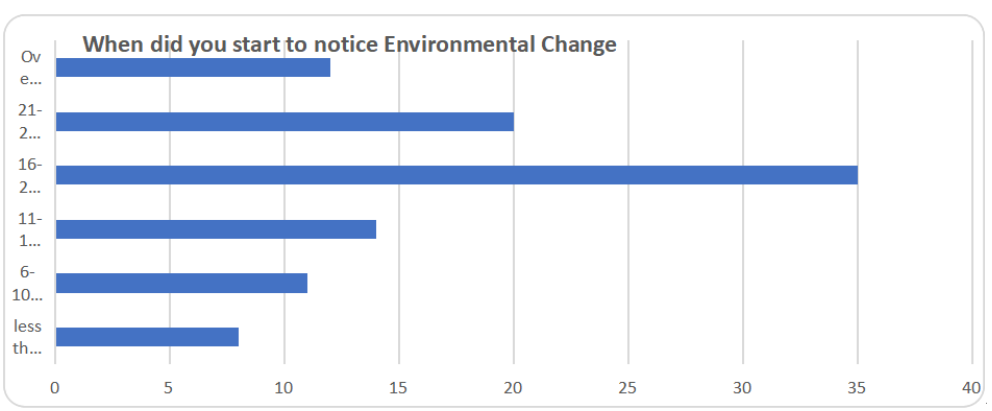

Figure 3. Awareness of Environmental Change

\subsection{Fluctuations/Reduction in Rainfall}

An overwhelming $82 \%$ of respondents perceive that today's climate is different from the past evidenced by change in seasonal cycles and rainfall patterns, increased average temperature and shorter cold season as well as more frequent droughts. The major changes associated with rainfall include the increased and unpredictable variations in rainfall, longer dry spells, increasing temperature and recurrent droughts over the last 20 years. FGD respondents in Nguru town recounted six major events since 1999 which described dry spells characteristic of droughts such as rainfall shortages and its attendant decline in soil moisture and overall productivity.

A participant in one of the FGDs describes how unpredictable the onset of the rainy season has become: "The onset of the rainy season has become so confusing; sometimes, the rains would come as early as April and disappear for an entire month or more. In the last three seasons, I have planted like three times in each planting season; and this happened to so many other farmers". Another participant describes the temperature: "The dry season is no longer what it used to be; the temperature is hot all the year round and it is so unbearable and we suffer a lot in this regard; and when the cold season sets in, it is so cold as if we have never experienced hot temperatures".

Indeed, $73 \%$ of respondents interviewed observed that late onset of the rains has a significant impact on the farming calendar and has affected production outputs.

While rainfall fluctuations are viewed as natural phenomena which have affected the size of the wetlands, $61 \%$ of interview respondents additionally noted that upstream water projects have also severely affected the size of the wetlands area. The older respondents in the FGDs vividly recalled the construction of the Tiga and Challawa 
Gorge dams on the Hadejia River and its tributaries which altered the river's natural flow pattern and annual floods, thereby significantly affecting the livelihoods of several communities.

\subsection{Typha Grass Invasion}

One of the most observable and well documented (IUCN, 2006; Idris, 2008; Blench, 2013) changes in the wetlands is the gradual invasion of flooded areas and water channels by Typha grass, locally known as "kachala". According to FGD respondents in Nguru, Typa grass first appeared in the early 1990s specifically in the rice and cassava fields. These invasive species usually block and redirect water flow resulting in blockages, siltation and flooding, diverting river flows and causing flooding of farmlands, roads and settlements. There is growing concern in all the communities about its rapid expansion and replacement of other native species, impacting negatively on new areas of invasion. Consequently, local farmers and grazers have been forced to over harvest available resources and encroach on protected areas. Respondents in Nguru town and Dumsari communities estimate that about $65 \%$ of lands hitherto used for cultivation, fishing and grazing have been colonized by Typha grass causing reduction in crop production and livestock output. FGD respondents reveal that most river channels are clogged by Typha grass leading to flooding of communities along the river banks while the clumps provide habitat for quelea birds. FGD participants in Bombori estimated that Typha grass currently covers roughly between $60-70 \%$ of the total enclosure of the Ruwan kanya reservoir and Hadejia Barrage, escalating the build-up of silt deposits. These are the among the two locations of perennial water in the area. Other problems which respondents attribute to the spread of the Typha grass include the occurrence of a vast breeding ground for freshwater snails, mosquitoes and other insects, linked to increased incidence of diseases like bilharzias and malaria. Invasion by Typa grass is also related to the roosting space for Quelea birds resulting in extensive crop damage, particularly rice and millet. Another environmental problem which FGD participants link to typa grass invasion is the intrusion of potash in the area thereby salinizing the soil and rendering it useless for agriculture and grazing.

\subsection{Unregulated Human Activities}

Human activities often practiced in an unregulated and unsustainable manner are a major contributory factor to environmental change. The activities identified by respondents include bush burning, overgrazing, deforestation and over-cultivation.

Bush burning: Most bush or grass fires in the area are attributed to uncontrolled burning of farm clearing for agriculture, hunting and regeneration of vegetation for livestock consumption. Fifty-seven percent (54\%) of respondents are aware that the effects of bush burning on the environment and livelihood activities is increasingly becoming extensive and damaging. Forty-one percent of respondents know that they are required by law to seek permission before setting wild fires but this regulation is rarely enforced. The traditional rulers (Bulamas and ardos) saddled with the task of monitoring such activities admit finding it difficult to enforce regulations due to lack of effective monitoring mechanisms and support from forestry officials. Thus, there is a high incidence of rampant bush fires which cause significant damage to the vegetation cover and eliminates seedlings of low fire resistant species and adversely affect the soil.

Overgrazing: Respondents to the questionnaire attributed overgrazing to limited rangeland due to increasing number of nomadic pastoralists that come from Niger republic and other far places as well as encroachment into demarcated grazing reserves and grazing routes by farmers which have reduced rangeland availability. Two main processes of overgrazing identified by the respondents: The first is said to occur when the size and number of herds is increased and secondly where the area of land available for grazing is reduced due to encroachment. The two processes have contributed to overgrazing in almost equal proportions according to respondents. Other underlying causes of overgrazing include increasing livestock populations, improved veterinary care, reduction of pasture due to encroachment by farmlands, settlement of nomads and the spread of commercial and irrigated agriculture. All these directly explain the size of herds that graze which has increased over the years as shown in Figure 4.

Deforestation and biodiversity loss: The indiscriminate cutting down of trees is a very common phenomenon in the area and $67 \%$ of interview respondents attributed this to the demand for fuel wood for cooking, smoking fish, making burnt bricks and clay pots as the major causes of deforestation. While most (58\%) are aware that this is a major problem, the lack of alternative energy sources and increasing populations have left communities with little or no choices but to continue cutting down of trees. Furthermore, commercial tree felling is a major livelihood activity particularly during the dry season. Traditional fuels such as trees, leaves, crop residues and cow dung supply about 95 percent of energy used. Most often, reduction in tree cover removes the protection that is afforded to soils. The study found that $56 \%$ of female respondents travel over $5.5 \mathrm{~km}$ to collect fuelwood. 
The women in the FGD indicated that key fuel wood species such as Khaya senegalensis and Anogeissusleiocarpus have vanished in the area. The women note that dry wood is usually gathered and live trees are left to grow but cutting live trees and tree lopping (browsing) have become common in recent times. The common tree species that have suffered severe degradation include Adansonia digitata (Baobab), Acacia nilotica (gum Arabic), Ziziphus Mauritania (magarya) and Balamites aegyptica (aduwa) as affirmed by the respondents.

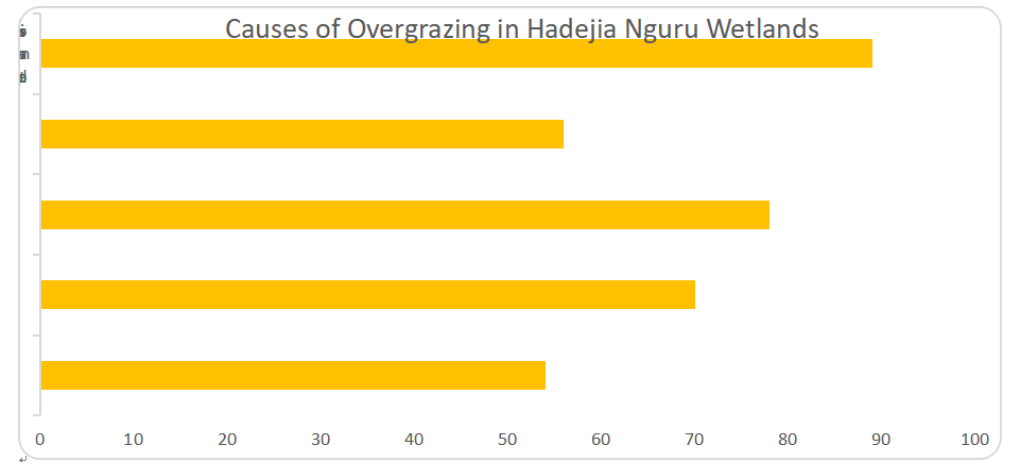

Figure 4. Causes of overgrazing in Hadejia-Nguru Wetlands

FGD respondents observed that wild trees such as baobab, tamarind trees which were once widely available and freely accessed have drastically reduced in recent years. Increasing demand for wild resources for household use and for sale by both male and female members of the communities were observed to be the reasons for over exploitation and biodiversity loss.

The FGD respondents noted that the wetland was once a major center of large mammals and reptiles and breeding sites of crocodiles and manatees as recorded in oral tradition. Some of the wild animals include Duikers and Jackals and warthog. The wetland is internationally recognized as a habitat for wintering Palaearctic bird species, particularly Afro-tropical water birds. Very large concentrations of such species were recorded in the 1980s and early 1990s where over sixty known bird species (Adams et al., 1993) were recorded. But recent censuses have recorded a dramatic fall in numbers, presumably due to the decreasing areas of surface water. The crowned crane, Balearicapavonina), once emblematic of the wetlands, has now completely disappeared. The only species regularly caught by hunters are various rats (Cricetomysetc), squirrels and the monitor lizards (Varanus spp.) which are smoked and sold in small numbers at urban centers such as Hadejia and Nguru.

While the fish resources of the Hadejia-Nguru wetlands are still extensive, fishermen report that the present day diversity is $42 \%$ what existed prior to the Challawa Gorge impoundment and typa grass invasion. Fish availability and variety significantly reduced due to flooding and dam related activities. This development is further compounded by industrial waste from tanneries discharged into the river at the upstream side thereby resulted in massive death of fish and other aquatic life (FGD with fishermen). Indeed, the degradation of habitats and loss of species is not always visible but it occurs in other more insidious ways with equally damaging results.

In areas where particular species such as hardwood trees, rattans, medicinal and food plants, and other non-timber forest products, are harvested unsustainably, not only are these species lost but a myriad of associated plants, such as insects and fungi, that require these specific hosts to meet their own ecological requirements for survival are also lost.

\subsection{Changes in Livelihood Activities and Adaptation Strategies}

This study found $82 \%$ of respondents engage in more than one livelihood activity namely farming and fishing. A study conducted by Birdlife International (2015) similarly showed that $75 \%$ of the indigenous community population are farmers and fishermen and the wetlands represents their entire source of livelihoods. The different resource user groups saw the changes in the environment from different point of views. Overwhelming majority of respondents $(81 \%)$ agreed that environmental change is negatively impacting on resource availability. All the reported changes have affected the livelihood of the people in many different ways and these are discussed below: 


\subsubsection{Change in farming activities}

The FGDs revealed that the most persistent issue regarding resource scarcity and environmental change in all communities was the shortage of productive irrigated land, and declining agricultural productivity under rain fed agriculture. Farmers identified loss of soil fertility, flooding, and unpredictable rainfall over the years as some of the factors that have altered agricultural production. Sixty-five percent of interview respondents indicated that crop yields have gradually decreased as a result of these changes. FGD participants further estimated that a hectare of land that used to produce 40 bags of millet 1999 produced 25 bags or even less of the same quality in 2019. Another frequently mentioned source of decline in productivity is invasion by birds due to habitat created by typha grass. Ironically, the study revealed that farmlands increased over the years, linked mainly to expansion in dry season farming, intrusion into grazing and forest reserves (which are not effectively managed/monitored) and expanding populations. However, there is no corresponding growth in per capita crop yield. This may not be unrelated to increasing populations and declining soil productivity which pose significant risk for agriculture productivity.

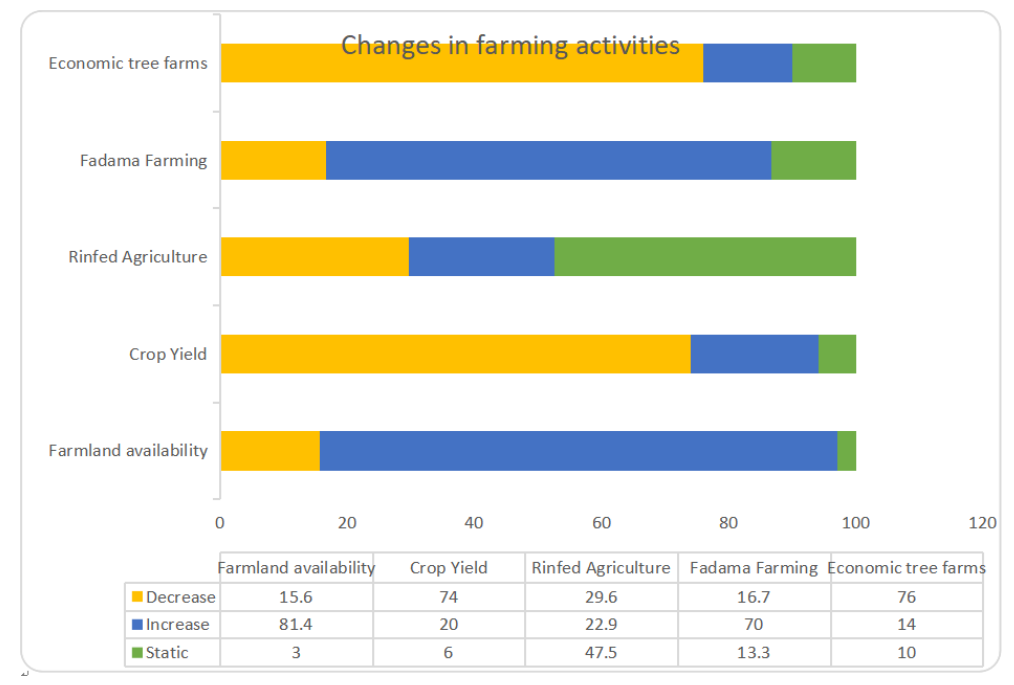

Figure 5.

\subsubsection{Changes in Fishing Activities}

The Hadejia-Nguru Wetlands is known as an important commercial fish source with fishing activities practiced in several communities. Some settlements are however known to depend entirely on fishing as a means of livelihood namely Bulabulin, Matara Uku, Kakori, Dumsai and Garbi. While men are mainly involved with catching fish, women are the ones that process and sale fish and fish products. Fishermen reported decline in water volume, quantity, quality and diversity of fishes. Seventy-four percent $(74 \%)$ of interview respondents indicated that some species of fish which existed in the past are no longer found due to declining water availability. The species are locally known as Tsage, Barva, Dunwno, Yawni, Kausa,Bana, and Burdo. The invasion of water bodies by Typha grass has also contributed significantly to the disappearance of fish species. The fish species commonly available are Dundukuri, Gaiwa, Sawavva, Tatir, Musko, Tarwada, Karfasa while Bargi have disappeared and reappeared six years ago. The respondents further revealed that the sizes of fish caught are relatively smaller now due to over fishing, the use of drag net locally known as Taru in Hausa. The reduction in water volume and Typa grass invasion has also reduced the size of fishing area. Eighty-five percent $(85 \%)$ of interview respondents assert that the size and volume of water in shallow lakes and rivers has reduced and indeed perennial water bodies now dry up during the dry season. The major fish market center in Nguru town was a widely recognized center for fish production and export to other parts of the country on weekly basis but the situation has changed dramatically in recent years. 


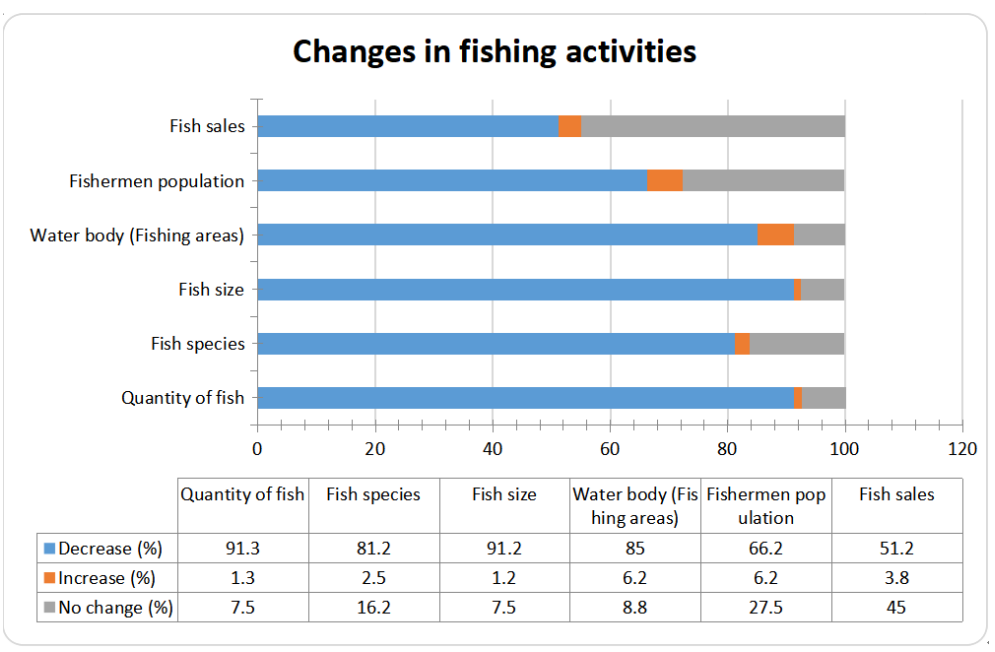

Figure 6. Changes in Fishing Activities

\subsubsection{Changes in Livestock Rearing and Pastoralism}

Livestock rearing is one of the important livelihood activities in the study area with most pastoralists found in distinct isolated temporary settlements known as Ruga mostly located less than $10 \mathrm{~km}$ to major settlements. There are also another group of pastoralists which are purely nomadic that come on seasonal basis to the area from neighboring countries of Niger and Chad Republics but none of them was involved in the study because they were not available at the time of conducting this field work.

Some of the changes reported by pastoralists include decline in grazing land and availability of pasture as well as encroachment into traditional cattle route and grazing reserves by farmers. Eighty-two percent of respondents perceived that grazing land in the study area had decreased due to continued expansion in both rain fed and irrigated agriculture. The FGDs further revealed that large areas of land where pasture can be found in abundance have now been converted into fields for rice and other farming irrigation. The pastoralists in Dumsai lamented that decrease in size of the Durnsai-Yamdigo grazing land was as a result of encroachment by farmers through the expansion of arable farming. Another form of encroachment identified by $81 \%$ of pastoralists is encroachment into officially gazetted grazing routes known as burtali which creates difficulties in accessing grazing reserves and livestock watering points. The major grazing routes that have witnessed significant encroachment include Burtal Balewa, Burtal Gandewa and the main Burtal that starts from Nguru and pass through Garin Alkali down to Geidam and into Chad Republic. This supports the finding by Blench (2013), that grazing reserves within the wetlands totaling an area of 8,000 hectares established by the Government have been significantly encroached by crop farmers. There are several other small reserves known as Hurmis established by Local Government Councils but are not protected and therefore heavily encroached by farmers.

The decline in pasture and consequently livestock numbers have also affected the sale of dairy products which is an activity mostly done by women affecting the pastoralists incomes.

\subsubsection{Changes in Hunting and Wildlife Activities}

Hunting used to be a major activity in the wetlands but it is now practiced by a limited number of people due to decline in wildlife populations. The wetlands used to be a major center of large mammals and reptiles as well as breeding sites of crocodiles (Adams et al., 1993). FGD respondents revealed that the Kano Zoological gardens was set up with two young lions captured in the wetlands in the early 1970s but such large mammals have long disappeared. Sixty-seven percent of respondents believe that wildlife resources are on the verge of extinction due to deforestation, reduction in water availability and inadequate monitoring and protection of wildlife resources. Wild animals like antelopes and guinea fowls have ceased to exist because of the decline in forest areas and because they were specifically targeted for game. The animals that are currently found include squirrels, hares, rabbits and rats. 


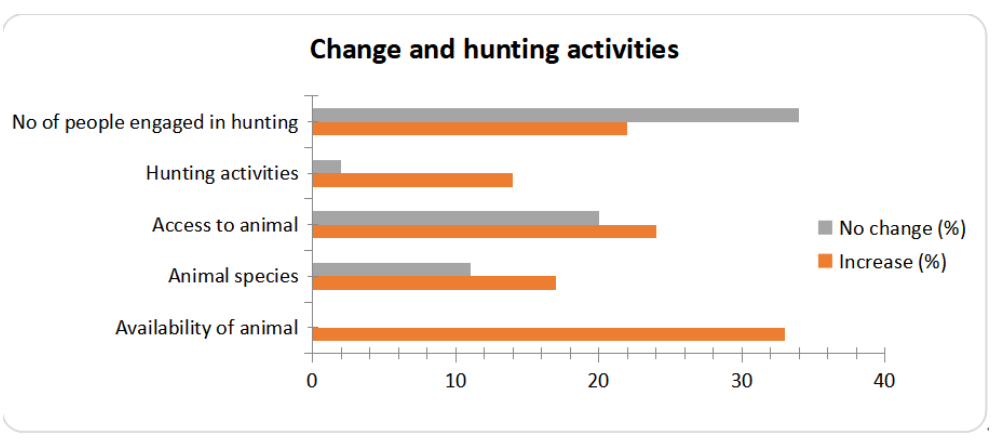

Figure 7. Effects of Environmental Change on Hunting Activities

\subsubsection{Change in Other Livelihood Activities}

Alongside farming, fishing, and herding, a significant number of the population also collect forest products (fruits, roots, leaves) for daily subsistence. While forest-based livelihoods are not discussed in depth in this study, it is important to highlight the key role that forests play in the area. Fuelwood including charcoal is the main source of domestic energy making up to $91 \%$ of households' total energy consumption. Forests also support livestock during the dry season by providing woody fodder. According to interview respondents, the utilization of forest products is generally at its peak when agricultural activities have subsided particularly during the dry season or droughts. Forest products contribute significantly in augmenting household food security.

Table 2. Change in other livelihood activities

\begin{tabular}{llll}
\hline Phenomena & Decrease (\%) & Increase (\%) & No change (\%) \\
\hline Cutting trees & 7.5 & 91.2 & 1.2 \\
Harvesting of Wild product & 80 & 12 & 8 \\
Available Forest area & 84 & 10 & 6 \\
\hline
\end{tabular}

\subsubsection{Coping and Adaptation Strategies to Environmental Change}

In order to properly understand what drives adaptation among resource users experiencing environmental change and resource decline, there is a need to consider what Smit et al., (1999) describes as 'what' is being adapted to, by 'whom,' and 'how' autonomous adaptation occurs. Several types of adaptive responses were observed in the study. Adaptation could be a means of reducing risks posed by resource scarcity, environmental change and increasingly as the result of climate change. In most cases, adaptation measures are spontaneous and not conscious responses often triggered by ecological changes in both natural and human systems.

FGD respondents described how the entire population is dependent on natural resources for livelihoods and how environmental change and resources decline over the years has forced them to adopt responses such as diversification and seek alternative livelihood sources. A dominant proportion of respondents (83\%) indicated that they have diversified their livelihood options and engage in additional activities such as fishing, livestock rearing, harvesting wild resources as well as trading. As earlier mentioned, $90 \%$ of the population engage in more than one livelihood activity. Livelihood diversification is driven by 'distressed' rather than 'progressive' reasons with users forced to develop alternative sources in addition to the main occupation.

The farmers revealed that they often use the same space consecutively for different activities namely rain-fed and irrigation farming following the rhythm of the annual floods and flood recessions. This also includes intensification of activities, for example, farming and rearing of animals, fishing and farming, rearing and trading of cattle, extraction of wild product. Garbi and Matara-Uku settlements were mainly recognized as fishing villages but $42 \%$ and $50 \%$ of the fishermen now engage in both rain-fed and irrigation farming.

In response to climatic fluctuations such as rainfall variability, most of the communities have developed rules-of-thumb responses based on their practical experience to monitor rainfall variability and likely impact on crop production and fishing activities. Thus managing rainfall variability in farm practices include traditional, locally managed activities such as pond excavation for retention of rainwater for moisture conservation, practices such as deep tube well facilitated irrigation practices, adoption of new short-duration and drought-tolerant crop varieties, and cultivation of different crops. Another response is through planting of trees to serve as source of 
wood production for fuel wood and backyard gardening. reduced herd size. Other adaptation practices include adoption of integrated crop-livestock farming systems. Pastoralist and fishermen respond to changing natural resources availability and accessibility through short distance and temporary migration. Another important response is through change of occupation, for example from pastoralism to farming, from fishing to farming.

\section{Conclusion and Recommendations}

Both natural and human activities are known to modify the natural environment, and Hadejia-Nguru wetland is not exceptional. The communities in the wetlands depend largely on the natural resources for their livelihood and survival. These natural resources have been significantly altered and continue to deplete due to unsustainable practices and over population. The natural resource scarcity that resulted from environmental changes have had severe impacts on communities through loss of biodiversity, soil productivity and accelerated environmental degradation thereby increasing vulnerability and reducing livelihood options. This hardship imposed led to a number of adjustments by individuals and communities to continue eking out a living within the same environment. However, the current community level of adaptation measures may not be sufficient to meet the challenges of the current environmental change particularly in the face of climate change.

It is therefore very important to improve the understanding of local populations and communities on the prevailing changes in their immediate environment because.

\section{Recommendations}

Based on the assessment and findings of this research, some recommendations are put forward:

$>$ Pastoralism is an important economic activity in the area that provides thousands of people with livelihood, Federal and State government should put more efforts on protecting the grazing reserves because predictions on the future of pastoralism appears very blink and pessimistic. Indeed, most resource users noted that pastoralism is perhaps the most threatened/endangered livelihood.

$>$ Tree planting campaign should massively re-introduced and encouraged at household levels so that the problems of deforestation are addressed.

$>$ Government should make provisions for alternatives to sources of energy such as the use of solar energy, kerosene, cooking gas etc. so that they are available and accessible at affordable price to the communities in the study area.

$>$ Environmental education and awareness programs should be re-emphasized to increase the awareness of the populace on causes, effect and mitigating measures of environmental change. In this regard, the North East Arid Zone Development Programme activities now moribund need to be resuscitated by Yobe State government.

Poverty eradication programs should also be introduced in the study area so as to have a shift from environmental based occupation like farming, fishing, hunting, pastoralism and wild product extraction to non-environmental based occupation such as trading, transport services, welding, plumbing, bricklaying, tailoring etc.

$>$ Enforcement of some environmental protection laws and policies so that indiscriminate cutting down of trees and encroachment by farmers into reserves is halted.

\section{Notes}

Note 1. The Ramsar Convention on Wetlands of International Importance especially as Waterfowl Habitat, commonly called the Convention on Wetlands, is an international treaty adopted in Ramsar (Iran) on 2 February 1971 for the conservation and sustainable use of wetlands. It is designed to halt their degradation and loss by recognising their ecological functions and economic, cultural, scientific, and recreational value. The Convention came into force on 21 December 1975.

\section{Conflict of interests}

The authors declare that there is no conflict of interests regarding the publication of this paper.

\section{Reference}

Abubakar, M. M., Kutama, A. S., Sulaiman, I. M., \& Ringim, A. S. (2016). Impact of Climate Change on the Hadejia-Nguru Wetlands: A Review Abubakar et al. Dutse Journal of Pure and Applied Sciences, 2(1), $150-158$.

Bird Life International. (2015). Important Bird Areas factsheet: Hadejia-Nguru wetlands. Cambridge, United Kingdom. 
Blench, R. (2013). An overview of the context of the Jewel project: Access rights and conflict over Common pool resources in the Hadejia-Nguru wetlands. A report prepared for the JEWEL project in the Hadejia-Nguru wetlands, report of ITAD, Cambridge CB1 2AL, United Kingdom.

Clay, N. (2017). Integrating livelihoods approaches with research on development and climate change adaptation. Progress in Development Studies, 18(1), 1-17. Sage Publications (Dietz et al., 2013). https://doi.org/10.1177/1464993417735923

Eaton, D., \& Sarch, M. T. (1997). The economic importance of wild resources in the Hadejia-Nguru wetlands, Nigeria. Thompson JR, Hollis GE (1995) Hydrological modelling and the sustainable development of the Hadejia-Nguru Wetlands, Nigeria. Hydrological Sciences Journal, 40, 97-116. https://doi.org/10.1080/02626669509491393

Idris, M. (2008). Damming Nigeria's Wetlands People: Communities Work Together to Restore Lives and Livelihoods. International Rivers IUCN (2019).

Kaugama, H. H., \& Ahmed, B. A. (2014). Prospect and Challenges of Farming along the Hadejia-Nguru Wetland in Jigawa State, Nigeria. International Journal of Academic Research in Economics and Management Sciences, 3(6), 43. https://doi.org/10.6007/IJAREMS/v3-i6/1279

Olalekan, E. I., Abimbola, L. M., Saheed, M., \& Damilola, O. A. (2014). Wetland Resources of Nigeria: Case Study of the Hadejia-Nguru Wetlands. Poult Fish WildlSci., 2, 123. https://doi.org/10.4172/2375-446X.1000123

Olalekan, E. I., Li-Hammed, M. A., Matemilola, S., \& Omosanya, A. D. (2014). "Wetland Resources of Nigeria: Case Study of the Hadejia-Nguru Wetlands". Poultry, Fisheries \& Wildlife Sciences, 2(2). https://doi.org/10.4172/2375-446X.1000123

Ramsar, C. (1994). Convention on Wetlands of International Importance Especially as Waterfowl Habitat. United Nations Educational, Scientific and Cultural Organization (UNESCO): Paris, France.

Thompson, J. R., \& Holliis, G. E. (1995). Hydrological Modeling and the sustainable development of the Hadejia-Nguru Wetlands. Nigeria Hydrological Sciences Journal, 40(1), 97-116. https://doi.org/10.1080/02626669509491393

Thompson, J. R., \& Polet, G. (2000). Hydrology and land use in a sahelian floodplain wetland. Wetlands, 20, 639-659. https://doi.org/10.1672/0277-5212(2000)020[0639:HALUIA]2.0.CO;2

United Nations Environment Program (UNEP). (2011). Climate Change, Conflict and Migration in the Sahel.

\section{Copyrights}

Copyright for this article is retained by the author(s), with first publication rights granted to the journal.

This is an open-access article distributed under the terms and conditions of the Creative Commons Attribution license (http://creativecommons.org/licenses/by/4.0/). 